УДК 616.895.4:616.89-008.441.13-056.34(510):550.87

Для цитирования: Ху Диан. Клинико-биологические исследования депрессий и алкогольной зависимости среди населения Китая. Сибирский вестник психиатрии и наркологии. 2019; 2 (103): 113-117. https://doi.org/10.26617/1810-3111-2019-2(103)-113-117

\title{
Клинико-биологические исследования депрессий и алкогольной зависимости среди населения Китая
}

\section{Ху Диан}

Харбинский медицинский университет

№ 157 Бэоджиэн-Роуд, Нэнгэнг-Дистрикт, Харбин-Сити, провинциия Хэйлунизян, Китайская Народная Республика, 150081

\section{PEЗЮME}

Харбинский медицинский университет проводит стратегию активного научного сотрудничества с зарубежными университетами по совместным медицинским программам, тенденция углубления межгосударственных и творческих контактов проявляется и во взаимодействии с российскими психиатрами. С этой целью осуществляется двустороннее сотрудничество по реализации медико-технологических проектов, в которых задействованы высококвалифицированные научные кадры, а разработки проводятся с привлечением современного оборудования. Китайские и российские психиатры видят свою задачу в избавлении современного глобального общества от психиатрической стигмы и в создании комплаентной основы для сотрудничества врача и пациента.

Ключевые слова: депрессия, алкогольная зависимость, клинико-биологические характеристики, этнопсихиатрия.

Харбинский медицинский университет имеет почти столетнюю историю, он был организован в 1926 г. Сейчас это передовой медицинский вуз, в структуру которого входят 5 аффилированных больниц. Здесь работают выдающиеся ученые, имена которых известны во всем мире. К примеру, исследования д-ра B.F. Yang в 2007 г. были оценены авторитетным медицинским научным журналом "Nature Medicine", публикующим результаты инновационных разработок в области биомедицины, как «одно из десяти достижений в области наук о жизни». Так как микроРНК задействованы в биологических процессах, связанных с развитием сердечно-сосудистой патологии, исследования в этом направлении имеют мировой приоритет. Активация микроРHKmiR-1 происходит у пациентов с нарушениями сердечной деятельности, перенесших инфаркт миокарда. Предоставлены доказательства того, что miR-1 опосредует электрическое ремоделирование предсердий при аритмии. Полученные данные вселяют надежду, что ингибирование miR-1 после инфаркта миокарда уменьшит риск внезапной смерти, что является столь распространенным финальным результатом у пациентов с сердечнососудистыми заболеваниями.

Направления исследований распространенности, клинико-динамического течения, терапии и прогноза депрессивных расстройств среди населения КНР связаны как с клинико- психиатрическим и патопсихологическим аспектами, так и с определением нейроэндокринологических и иммунологических параметров при депрессии. С этой целью проводится исследование уровня глиофибриллярного кислого белка в сыворотке крови пациентов с первым эпизодом депрессии. Осуществляется попытка определить корреляционные связи между уровнем $\gamma$-аминомасляной кислоты в плазме крови и нарушением когнитивных функций со снижением познавательных процессов и адаптационного потенциала при депрессии. Исследуются показатели амилоида и галанина в плазме крови у пациентов с депрессивными расстройствами. Продолжено изучение динамики гормональных полипептидов (окситоцина и аргининвазопрессина) в плазме крови у женщин с первым эпизодом депрессии. Найдены коррелятивные связи между сниженным уровнем мелатонина и первым эпизодом депрессии. Проведен анализ и сопоставление нейроэндокринных параметров у пациентов с суицидальными идеями и без них. Осуществлены исследования ассоциации между метилированием промотора SLC6A4 и большим депрессивным расстройством. Изучена клиническая структура депрессий с суицидальными идеями и без них, установлены потенциальные корреляции с негативными событиями в жизни пациентов. Изданы рекомендации по диагностике и лечению депрессии и биполярного расстройства. 
Исследования алкогольной зависимости на модели различных возрастно-половых групп, имеют продвинутый научно-практический уровень в Китае. В проектную команду входит руководитель исследовательской группы психиатрического отделения Китайской медицинской ассоциации по борьбе со злоупотреблением психоактивными веществами.

Разработчиками проводится углубленное изучение биохимических процессов и обусловленных ими изменений в головном мозге в результате хронического злоупотребления алкоголем. На экспериментальной модели крыс с хроническим алкоголизмом получены доказательства, что прием флуоксетина может облегчить органическую симптоматику вследствие повреждения головного мозга и гиперкортизолемию в связи с синдромом зависимости от алкоголя.

Выявлена взаимосвязь в зависимости от полиморфизма генов между уровнем серотонина в головном мозге и алкогольной зависимостью на материале исследовательской выборки китайских ханьцев - представителей преобладающей национальности в провинции Хэйлунцзян. По результатам генетических исследований обнаружено, что полиморфизм гена 5HTR1B, гена DRD2, гена TaqIA и метаботропного глутаматного рецептора 3 (GRM3) связан c предрасположением к развитию алкогольной зависимости в китайской популяции ханьцев, что можно расценивать как новую мишень, на которую должно быть направлено внимание при лечении алкоголизма $[1,2]$.

Проводится комплексное исследование изменений функции головного мозга с привлечением разных инструментально-измерительных методов (магнитно-резонансная спектроскопия, определение однонуклеотидного полиморфизма, оценка когнитивных способностей) в выборке ханьцев, злоупотребляющих алкоголем. Еще один важный вектор исследовательских разработок - анализ дифференциальной экспрессии и направленный анализ МіРНК в сыворотке крови мужчин-алкоголиков - жителей провинции Хэйлунцзян.

Кроме того, на данном этапе особенно актуальны когортные эпидемиологические аналитические исследования распространенности и течения алкоголизма и изучение связанных с ним медико-социальных последствий (формирование основных форм психических заболеваний среди населения приграничных регионов Китая и Дальнего Востока России).
С помощью компьютерной томографии выявлена структурная атрофия мозжечка, вызванная алкогольной зависимостью. Применение однофотонной эмиссионной компьютерной томографии позволило обнаружить, что региональный мозговой кровоток (rCBF) снижался во многих областях головного мозга пациентов, страдающих алкоголизмом, включая двустороннюю лобную долю, височную долю, теменную долю, поясную извилину, парагиппокампальную извилину, таламус, мозжечок.

Кроме того, у лиц с алкогольной зависимостью зарегистрированы более низкие уровни концентрации N-ацетиласпартата и креатина (одна из концентраций метаболитов головного мозга) в левой префронтальной области серого вещества и белого вещества по сравнению с контрольной группой, так же как и результаты теста оценки исполнительных функций были более низкими, что позволяет предположить, что долгосрочные хронические заболевания, такие как алкоголизм, снижают активность и жизнеспособность нейронов и когнитивные функции. Алкоголизация приводит к пищевым нарушениям в связи с недоеданием и истощению организма, а также к метаболическому синдрому. Выявленный дефицит витамина В и других веществ в крови алкоголизирующихся лиц приводит к энцефалопатии Вернике.

В ближайшем будущем планируется проведение исследований с использованием диффузионной тензорной магнитно-резонансной томографии (Diffusion Tensor Imaging) у пациентов с алкоголизмом.

Патофизиологические исследования показывают снижение числа нейронов в мозге лабораторных крыс на фоне воздействия алкоголя. Инновационное лечение стволовыми клетками, очень популярное в последние 10 лет, показало, что мезенхимальные стволовые клетки могут ингибировать хроническое вызванное этанолом окислительное повреждение у крыс [3, 4].

Международное сотрудничество с Black Dog Institute (Школа психиатрии, Университет Нового Южного Уэльса, Австралия) проходит в русле изучения проблемы коморбидности биполярного расстройства и алкогольной зависимости. В кооперативно подготовленном обеими сторонами документе «Существуют ли какиелибо клинические или демографические различия между больными биполярным расстройством с коморбидным расстройством и без него?» отражены основные результаты исследовательской работы единой научной команды. 
В наших позитивных планах намечено продолжение сотрудничества с российскими психиатрами, достижение корпоративными усилиями плодотворных результатов в научных исследованиях, коммуникативное взаимодействие и общение, устранение языковых и межнациональных барьеров.

\section{ЛИТЕРАТУРА}

1. Xia Yan, Wu Zheng, Ma Dongying, Tang Chunling, Liu Lei, XinFeng, Zhu Daling, Hu Jian. Association of single-nucleotide polymorphisms in a metabotropic glutamate receptor GRM3 gene subunit to alcoholdependent male subjects. Alcohol and Alcoholism. 2014; 49(3): 256-260. http://www.biomedsearch.com/nih/AssociationSingle-Nucleotide-Polymorphisms-in/24585043.html

2. Xia Yan, Ma Dongying, Hu Jian, Tang Chunling, Wu Zheng, Liu Lei, Xin Feng. Effect of metabotropic glutamate receptor 3 genotype on $\mathrm{N}$ acetylaspartate levels and neurocognition in non- smoking, active alcoholics. Behavioral and Brain Functions. 2012; 8 (1): 42. DOI: 10.1186/17449081-8-42

3. Hu Jian, Xia Yan, Wu Zheng, Liu Lei, Tang Chunling. Fluoxetine Might Alleviate Brain Damage and Hypercortisolemia Related to Chronic Alcohol in Rats. Journal of Studies on Alcohol and Drugs. 2010, 71(2): 290-4. DOI: 10.15288/jsad.2010.71.290

4. Lei Liu, Jin-Xia Cao, Bo Sun, Yan Xia, Zheng Wu, Chun-ling Tang, Jian Hu. Mesenchymal stem cells inhibition of chronic ethanol-induced oxidative damage via upregulation of PI3K/Akt and modulation of ERK 1/2 activation in PC12 cells and neurons. Neuroscience. 2010, 2; 167(4): 1115-24. https://doi.org/10.1016/j.neuroscience.2010.01.057

Поступила в редакцию 13.02.2019 Утверждена к печати 8.04.2019

Ху Диан, профессор Харбинского медицинского университета.

УДК 616.895.4:616.89-008.441.13-056.34(510):550.87

For citation: Hu Jian Clinical-biological studies of depressions and alcohol addiction among the population of China. Siberian Herald of Psychiatry and Addiction Psychiatry. 2019; 2 (103): 113-117. https://doi.org/10.26617/18103111-2019-2(103)-113-117

\title{
Clinical-biological studies of depressions and alcohol addiction among the population of China
}

\section{Hu Jian}

\author{
Harbin Medical University \\ 157 Baojian Road Nangang District, Harbin-City, Province of Heilongjiang \\ People's Republic China, 150081
}

\section{ABSTRACT}

Harbin Medical University pursues the strategy of active scientific cooperation with foreign universities according to joint medical programs, the trend of deepening of interstate and creative contacts is shown also in interaction with Russian psychiatrists. Bilateral cooperation in implementation of medico-technological projects in which highly qualified scientific staff is involved is for this purpose carried out, and is developed with involvement of the modern equipment. Chinese and Russian psychiatrists consider their task in removal of psychiatric stigma in the modern global society and in creation of a compliant basis for cooperation of the doctor and the patient.

\section{Keywords: depression, alcohol dependence, clinical and biological characteristics, ethnopsychiatry.}

Harbin Medical University has almost centenary history, it was founded in 1926. Now it is the advanced medical school which structure includes 5 affiliated hospitals. Here outstanding scientists work whose names are known worldwide. For example, research by Dr. B.F. Yang in 2007 was evaluated the authoritative medical scientific journal "Nature Medicine" publishing results of the innovative developments in the field of biomedicine as "one of ten achievements in the field of life sciences". As microRNAs are involved in the biological processes connected with development of cardiovascular pathology, research in this direction has a world priority. Activation of mikroRNKmir-1 happens in patients with disturbances of cardiac activity who had a myocardial infarction. Proofs that miR-1 mediates electric remodeling of the atrium in arrhythmia are provided. The obtained data inspire hope that miR-1 inhibition after a myocardial infarction will reduce risk of sudden death that is so widespread final result in patients with cardiovascular diseases.

The directions of research of prevalence, clinicaldynamic course, therapy and prognosis of depressive disorders among the population of the People's Republic China are connected both with clinical-psychiatric and pathopsychological aspects, and determination of neuroendocrine and immunological parameters in depres- 
sion. The investigation of level of glial fibrillary acidic protein is for this purpose conducted in blood serum of patients with the first episode depression. The attempt to define correlation between level of $\gamma$-aminobutyric acid in blood plasma and disturbance of cognitive functions with decrease in informative processes and adaptation potential in depression is made. Indices of amyloid and galanin in blood plasma in patients with depressive disorders are investigated. Study of dynamics of hormonal polypeptides (oxytocin and arginine - vasopressin) in blood plasma in women with the first episode depression is continued. Correlations between the reduced level of melatonin and the first episode depression are found. The analysis and comparison of neuroendocrine parameters in patients with suicidal ideation and without it is carried out. Investigations of association between methylation of SLC6A4 promoter and Major Depressive Disorder are conducted. The clinical structure of depressions with the suicidal ideation and without it is studied; potential correlations with negative life events experienced by patients are established. The recommendations about diagnosis and treatment of depression and bipolar disorder are published.

The research of alcohol addiction conducted on model of various age and sex groups has advanced scientific and practical level in China. The Head of research group of Psychiatric Department of the Chinese Medical Association for counteraction against substance abuse enters into project team.

Developers carry out in-depth study of biochemical processes and changes caused by them in the brain in result of chronic alcohol abuse. On experimental model of rats with chronic alcoholism proofs are received that intake of fluoxetine can facilitate organic injury of the brain and hypercortisolemia connected with the syndrome of alcohol dependence.

The interrelationship depending on gene polymorphism between serotonin level in the brain and alcohol addiction on the material of study sample of the Chinese Han - representatives of the prevailing nationality in the Province of Heilongjiang is revealed. According to results of genetic studies it is revealed that the polymorphism of gene 5-HTR1B, gene DRD2, gene TaqIA and metabotropic glutamate receptor 3 (GRM3) is associated with predisposition to development of alcohol addiction in the Chinese population of Han that can be regarded as a new target at which the attention during treatment of alcoholism has to be directed [1,2].

The complex research of changes of function of the brain with involvement of different tools and measuring methods (magnetic-resonance spectroscopy, determination of one-nucleotide polymorphism, assessment of cognitive abilities) among the Han abusing alcohol is conducted. One more important vector of research developments - the analysis of a differential expression and the directed analysis of miRNA in serum of blood of alcoholic males - residents of the Province of Heilongjiang.

Besides, at this stage the cohort epidemiological analytical studies of prevalence and course of alcoholism and study of the related medico-social consequenc- es are especially relevant (formation of the main forms of mental diseases among the population of border regions of China and the Far East of Russia).

By means of the computer tomography the structural atrophy of the cerebellum caused by alcohol addiction is revealed. Use of a one-photon emission computer tomography allowed to find that the regional cerebral blood flow (rCBF) decreased in many areas of the brain of patients having alcoholism including bilateral frontal lobe, temporal lobe, parietal lobe, cingulate gyrus, parahippocampal gyrus, thalamus, and cerebellum.

Besides, in persons with alcoholic dependence lower levels of concentration of $\mathrm{N}$-acetylaspartate and creatinine (one of concentration of metabolites of the brain) in the left prefrontal area of gray matter and white matter in comparison with control group as well as test results of assessment of executive functions were lower that allows to assume that long-term chronic diseases, such as alcoholism, reduce activity and viability of neurons and cognitive dysfunctions are registered. Alcoholization leads to nutritional disturbances in connection with malnutrition and to organism exhaustion and also to a metabolic syndrome. The revealed deficiency of vitamin B and other substances in blood of abusing alcohol leads persons to Wernicke's encephalopathy.

In the near future carrying out the research with use of Diffusion Tensor Imaging in patients with alcoholism is planned.

Pathophysiological studies show decrease in number of neurons in the brain of laboratory rats against the background of alcohol influence. The innovative treatment with stem cells, being very popular in the last 10 years, showed that mesenchymal stem cells can inhibit in rats the chronic oxidative damage caused by ethanol $[3,4]$.

The international cooperation with Black Dog Institut (School of Psychiatry, the University of New South Wales, Australia) takes place in the course of study of the problem of comorbidity of bipolar disorder and alcoholic dependence. In the cooperatively prepared by both parties document "Whether There Are Any Clinical or Demographic Differences between Patients with Bipolar Disorders with Comorbid Disorder and without It?" the main results of research of united scientific team are outlined.

In our positive plans we consider continuation of cooperation with the Russian psychiatrists, achievement by corporate efforts of fruitful results in scientific research, communicative interaction and communication, elimination of language and international barriers.

\section{REFERENCES}

1. Xia Yan, Wu Zheng, Ma Dongying, Tang Chunling, Liu Lei, XinFeng, Zhu Daling, Hu Jian. Association of single-nucleotide polymorphisms in a metabotropic glutamate receptor GRM3 gene subunit to alcoholdependent male subjects. Alcohol and Alcoholism. 2014; 49(3): 256-260. http://www.biomedsearch.com/nih/AssociationSingle-Nucleotide-Polymorphisms-in/24585043.html 
2. Xia Yan, Ma Dongying, Hu Jian, Tang Chunling, Wu Zheng, Liu Lei, Xin Feng. Effect of metabotropic glutamate receptor 3 genotype on $\mathrm{N}$ acetylaspartate levels and neurocognition in nonsmoking, active alcoholics. Behavioral and Brain Functions. 2012; 8 (1): 42. DOI: 10.1186/17449081-8-42

3. Hu Jian, Xia Yan, Wu Zheng, Liu Lei, Tang Chunling. Fluoxetine Might Alleviate Brain Damage and Hypercortisolemia Related to Chronic Alcohol in Rats. Journal of Studies on Alcohol and Drugs. 2010, 71(2): 290-4. DOI: 10.15288/jsad.2010.71.290

Hu Jian, Professor of Harbin Medical University, China
4. Lei Liu, Jin-Xia Cao, Bo Sun, Yan Xia, Zheng Wu, Chun-ling Tang, Jian Hu. Mesenchymal stem cells inhibition of chronic ethanol-induced oxidative damage via upregulation of PI3K/Akt and modulation of ERK 1/2 activation in PC12 cells and neurons. Neuroscience. 2010, 2; 167(4): 1115-24. https://doi.org/10.1016/j.neuroscience.2010.01.057

Received February 13.2019 Accepted April 08.2019 